\title{
The Swiss flood and landslide damage database 1972-2007
}

\author{
N. Hilker, A. Badoux, and C. Hegg \\ Swiss Federal Research Institute WSL, Birmensdorf, Switzerland
}

Received: 22 October 2008 - Revised: 10 June 2009 - Accepted: 11 June 2009 - Published: 23 June 2009

\begin{abstract}
In Switzerland, floods, debris flows, landslides and rockfalls cause damage every year affecting property values, infrastructure, forestry and agriculture. As population and settled areas have increased, the damage potential has also become greater. Information about natural hazard events that caused any damage is needed for hazard mapping and further decision making. This is why the Swiss Federal Research Institute WSL has been systematically collecting information on flood and mass movement damage in a database since 1972. The estimated direct financial damage as well as fatalities and injured people have been documented using press articles as the main source of information. The database can provide answers to questions related to the temporal and spatial distribution of damage, natural hazard processes and the corresponding weather conditions. This study describes the data collection methods used and the key analyses of data from 1972 to 2007 . Furthermore, the benefits and drawbacks of the database are discussed. In Switzerland, naturally triggered floods, debris flows, landslides and rockfalls have caused financial damage amounting to nearly 8000 million Euros in total within the last 36 years (taking inflation into account). These processes have mainly affected pre- and central alpine regions and their total costs of damage are dominated by a few major events. Nearly one quarter of the costs result from August 2005 when large parts of Northern Switzerland were affected by flooding. We must assume that major events like this are not unique and that similar events will occur again in future.
\end{abstract}

\section{Introduction}

Each year, natural hazard events such as floods and landslides cause considerable financial damage to society. In Europe there have been several major events in the last few years. Floods in the catchment areas of the Elbe and the Danube

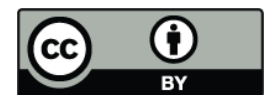

Correspondence to: N. Hilker (nadine.hilker@wsl.ch) in August 2002 resulted in 38 fatalities and financial damage amounting to more than 18000 million Euros (estimate up to the end of 2002). For Germany, this event represented the most costly natural catastrophe in history (approximately 11600 million Euros in total or 140 Euros per capita). Major damage was also registered in Austria, the Czech Republic and Slovakia (Destatis, 2008; Munich Re Group, 2003; Petrow et al., 2006; Thieken et al., 2006). In August 2005, large parts of Switzerland were flooded or affected by landslides and debris flows. Besides six casualties, an estimated financial loss of 1870 million Euros (or 250 Euros per capita) was recorded. The event was identified as the most costly for the country in at least the past 100 years (FSO and FOEN, 2008; Hilker et al., 2007). In summer 2007, parts of Great Britain were affected by extreme rainfall causing unprecedented hydrological conditions in the country's recent history at this time of year. Fourteen fatalities were due to three flood events, which occurred in June and July and the financial damage amounted to about 8000 million US \$ (corresponding to more than 5400 million Euros or 90 Euros per capita with the exchange rate on 31 December 2007) (Marsh and Hannaford, 2007; Munich Re Group, 2008; UK Statistics Authority, 2008).

Such severe events in recent years are clear evidence of the kind of impact natural hazards can have on society. As in many other countries, the population and extent of settled areas have increased in Switzerland over the last few decades (FSO and FOEN, 2008). Hence, the potential for damage has also become greater. On the other hand, numerous protection measures prevent at least smaller events from having too large an impact.

It is not only insurance companies that have an interest in records of natural hazard events. Local authorities in Switzerland also need such information to complete the mapping of natural hazards. This has involved a great deal of work at the request of the federal administration and is still in progress in some regions and already completed in others. To evaluate protection requirements and to plan for land use, it is necessary to know as much as possible about natural hazard processes and their impact (FOWG, 2001). Here

Published by Copernicus Publications on behalf of the European Geosciences Union. 
the documentation of historical events can provide an important basis for understanding these processes, which is why the Swiss Federal Research Institute WSL has been systematically collecting and maintaining information on flood, debris flow, landslide and (since 2002) rockfall damage in a database since 1972 (Hegg et al., 2000). In this project, the estimated direct financial damage as well as casualties originating from naturally triggered events have been recorded. The data are provided as a broad basis of information to official institutions responsible for land-use planning and for providing protection against natural hazards. Moreover, an analysis of data is published annually in the journal "Wasser Energie Luft" of the Swiss Water Management Association (e.g. Hilker et al., 2008). The data are also regularly integrated in the cadastre "StorMe" (Burren and Eyer, 2000), a superordinated database which the Federal Office for the Environment FOEN makes available to the Swiss cantons as computing support for documenting natural processes.

The literature about the damage caused by natural hazards (e.g. floods and landslides) often deals with the methodology of tangible loss estimation (Blong, 2004; Merz, 2006; National Research Council, 1999; Smith and Ward, 1998), and the accuracy or limitations of such approximations (Changnon, 2003; Downton and Pielke, 2005; Merz et al., 2004). There have also been several investigations into fatalities due to floods (Jonkman, 2005; Mitchell, 2003) and landslides (Guzzetti et al., 2005; Tropeano and Turconi, 2004). Tschoegl et al. (2006) provide an overview of several databases for natural disasters on global, regional or national levels. Global databases that include estimations of flood or landslide damage are also mentioned in Guha-Sapir and Below (2002), Munich Re Group (2003) and Petley et al. (2005). There are several national databases comparable to the Swiss one (Australia: Blong, 2004; Ireland: Creighton, 2006; Italy: Guzzetti and Tonelli, 2004; Nicaragua: Devoli et al., 2007; Slovenia: Komac et al., 2007) as well as regional databases (Azores/Portugal: Gaspar et al., 2004; Catalonia/Spain: Barnolas and Llasat, 2007; Hong Kong/China: Chau et al., 2003, 2004).

A comparison with foreign damage databases on a regional or national level might be valuable to improve our own data collection. Most data collections are based on press articles, scientific reports, government papers or existing databases. Due to the large variability of existing inventories, we only mention and briefly describe four examples of databases similar to our database.

The research centre Risk Frontiers maintains a database on natural hazards and their impacts in Australia (Blong, 2004). For insurance interest, it focuses on building damage and has compiled a building damage index allowing easy comparison between events. However, damage to other objects is not recorded. The Italian National Research Council collects historical information on landslides and floods in Italy in the AVI (Damaged Urban Areas) archive (Guzzetti and Tonelli, 2004). This database is comprehensive and is used for sci- entific and technical applications. The Latin American Network for Social Studies on Disaster Prevention (LA Red) developed the DesInventar concept and methodology (Tschoegl et al., 2006). DesInventar maintains several natural and technological disaster databases mainly in Latin American countries or regions, and facilitates the analysis and description of disastrous events on a local scale (DesInventar, 2008). HOWAS, held at the Bavarian Water Management Agency, is the most comprehensive flood damage database in Germany, and is focused on the financial damage on buildings (Merz et al., 2004).

First steps towards a standard for the documentation of natural mountain hazards data have been taken by the project DOMODIS (Documentation of Mountain Disasters) (Hübl et al., 2002). However, no widely perceived international norm for the management of a damage database has been proposed in the literature. The flood and landslide database presented in this paper provides a possible method for such an inventory on a national or regional scale. This article is intended to foster an exchange of experience with other institutions maintaining similar databases.

Furthermore, few long-term series of damage data exist to analyse trends. With 36 years of data collection, it is still difficult to draw general conclusions in a reliable way. However, it is possible to identify some of the different damagecausing processes, the triggering meteorological factors and the temporal and spatial distribution of damage during the period 1972-2007 and these are summarised in this paper. In addition, we briefly describe the six major natural hazard events since 1972 and discuss the advantages and disadvantages of the presented database methodology.

\section{Materials and methods}

\subsection{Sources of information}

Since 1972, data on damage caused by naturally triggered flood, debris flow, landslide and (since 2002) rockfall events in Switzerland have been systematically collected. Approximately 3000 Swiss newspapers and magazines are the main source of information. They are scanned by a mediamonitoring company for information about damage caused by the processes listed above. In some cases (e.g. to validate uncertain data or in the case of large events) insurance companies, official sites or the Internet (e.g. the police and fire brigade websites) are also consulted.

\subsection{Structure of the database}

The relevant information is then entered into a FileMaker Pro ${ }^{\mathrm{TM}}$ database following a standard routine. One dataset is generated for each natural hazard damage event. If more than one local authority (community) is affected by a single event, a single dataset is generated for each local authority. 
Table 1. Different object types in the database for which financial damage estimates are available.

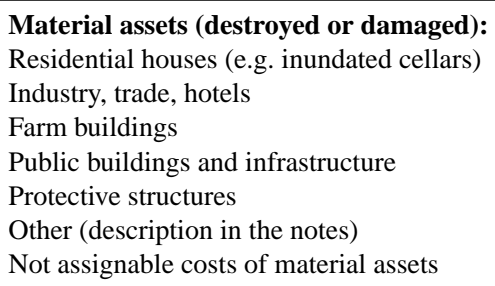

Traffic lines/infrastructure (damaged, buried and/or interrupted):

Motorways and national roads

Main roads

Other roads

Railway lines

Transport systems, cables, pipelines, pylons

Pilotages

Not assignable costs of traffic lines/infrastructure

\section{Forestry/agricultural land:}

Forest (affected area and wood)

Agricultural land (affected area)

The information collected in the database includes:

- Locality

- Date and time

- Type of damage-causing process and secondary processes

- Triggering weather conditions

- Description of the event

- Number of dead, injured and evacuated people and animals

- Affected objects (Table 1) and estimated direct cost of damage

- Further information or details, if available (stream discharge, deposited debris volume, etc.), can be entered in words in a note field.

The location of an event is indicated by the community, canton, watershed and coordinates. This information allows the data to be spatially analysed. The coordinates of the main damage per event and local authority are defined by using a linked geographic information system (ArcView by ESRI). Damage which cannot be assigned to a certain local authority is allocated to the capital of the affected canton or, if even the canton is unknown, to the Swiss capital (Bern). If possible, the date of an event and the starting time should be recorded or, if necessary, estimated, but the starting time can be left.

According to the main damaging process the dataset of a specific event is assigned to one of the following categories: landslide, flood/debris flow or rockfall. Because of the large variety of possible natural processes, the boundaries between these three groups are often blurred. Sliding or creeping movements of soil, slope-type debris flows and subsidence of ground fall into the category of "landslides". "Flood/debris flow" includes the actual flooding process by rivers or lakes (inundation) as well as erosion and deposition of material along a channel. The term "rockfall" includes all events caused by falling and sliding rocks of any size. It must be considered that this category has only been systematically recorded since 2002. Damage caused by avalanches, snow pressure, drought, earthquakes, lightning, hail and heavy gales are not taken into account in the database presented here.

Secondary processes, i.e. processes of a different type which occur at the same time, can also be listed. However, it is not always easy to differentiate between the various processes taking place or to decide which process is the most important one. Some damage is not exclusively influenced or caused by natural processes. Financial losses obviously due to the malfunction or under-dimensioning of (protective) structures are recorded nevertheless.

The triggering weather conditions can mostly also be identified, and are integrated in the database. A four group classification is defined: thunderstorm (high-intensity, shortduration rainfall), long-lasting rainfall, snowmelt (mostly associated with rainfall) and unknown/other causes. If possible, precipitation data are entered as well.

\subsection{Estimation of damage costs}

Insured property damage as well as not-insured or notinsurable material damage is considered in the database. Direct financial damage in Swiss Francs (CHF) is estimated according to the information sources. These estimates are largely based on experience. Empirical values originate from insurance evaluations, damage experts, emergency task forces and official sites. The quality of the estimates can be evaluated by assigning to them codes which range from a measurement over an estimate to a not-definable value. If possible, costs are associated with a certain type of affected object (Table 1). These are classified into "material assets" (destroyed or damaged buildings, protection structures, vehicles, etc.), "traffic lines/infrastructure" (transportation routes, power-supply and telephone lines, etc.) and "forestry/agricultural land". Beside the assessment of financial damage, further fields can be filled in, if the information sources give additional details, e.g. the number of residential houses affected or the length of road buried.

Indirect losses, later reconstruction measures and intangible damage (e.g. fatalities, irreparable damage to nature and environment) are not included in these estimates of monetary values. Instead, the numbers of dead, injured and evacuated people and animals are recorded.

In this article, data are given in Euros (value as at 10 July 2008: $1 €=1.62 \mathrm{CHF}=1.57$ US $\$$ ) and for events that 


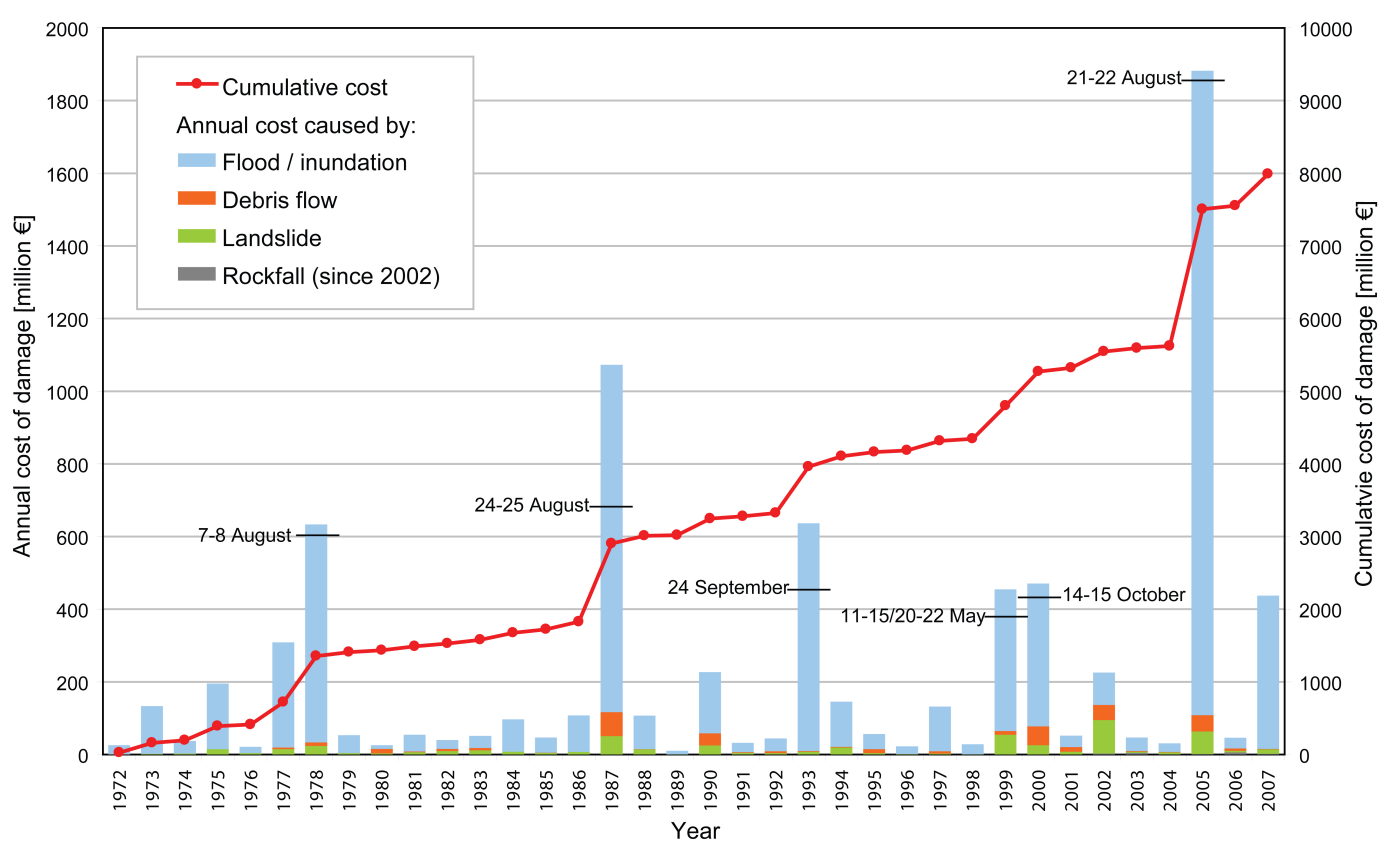

Fig. 1. Annual and cumulative cost of damage caused by floods/inundation, debris flows, landslides and rockfalls in the period 1972-2007, as well as the total costs of the six major flood events indicated by short horizontal lines and date. The p-value for the total cost of damage is 0.29 , which indicates there is no statistically significant trend in the data.

occurred in Switzerland inflation is always taken into account (base year 2007). To evaluate trends, we applied the MannKendall test and a significance level of 0.1 for the resulting p-value.

\section{Results}

\subsection{General results for the period 1972-2007}

Since 1972, storm events in Switzerland have caused damage amounting to approximately 8000 million Euros in total (Fig. 1). Thus, the average annual financial cost of damage due to floods, debris flows, landslides and rockfalls is about 220 million Euros in the period 1972-2007 ( $\sigma=586$ million Euros). The median of the yearly damage is, however, only about 55 million Euros. Compared to the average, this shows that only a few years exhibit exceptionally high costs. More precisely, in 26 of the 36 years investigated, i.e. $72 \%$, the total cost of damage was lower than the long-time average. The mean annual financial loss per capita amounts to approximately 32 Euros (with population development taken into account). A statistically significant trend for the total damage during the years 1972-2007 was not identifiable, as the high p-value of 0.29 indicates.

The total amount of damage was strongly influenced by a few severe events. Six single flood events in the years 1978, 1987, 1993, 1999, 2000 and 2005, causing damage costing more than 350 million Euros each, contributed $56 \%$ of the total sum. These major events are described in Sect. 3.2. The corresponding years of the six major events are also the ones with the largest amount of damage. In the year 2007, damage of more than 400 million Euros was recorded. However, this amount does not result from one single event, but from four distinct events (Hilker et al., 2008). In the years 1976, 1989 and 1996 the lowest yearly costs (less than 25 million Euros) were recorded.

The percentage of the total damage ( 8000 million Euros) caused by the different processes in the investigated period are the following (Table 2): whereas $89 \%$ of the costs (7110 million Euros) originate from floods and inundations, debris flows induced only about 4\% (340 million Euros), landslides 6\% (520 million Euros) and rockfalls less than $1 \%$ (15 million Euros) of the total costs. Regarding the four mean processes individually, there has been a slight increase in debris flow damage since 1972, and the Mann-Kendall test results in a p-value of 0.01 . No statistically significant trend can be identified concerning floods $(p=0.50)$ and landslides $(p=0.21)$, and six years is too short a period to draw conclusions about rockfall.

Long-lasting rainfall caused $75 \%$ (6000 million Euros; $p=0.34$ ) of the total loss, and thunderstorms $23 \%$ (1850 million Euros; $p=0.72$ ) (Table 3). Snow melt led to less than $1 \%$ (45 million Euros; $p=0.17$ ) of the costs, but played a role in combination with continuous rain, e.g. during the flood of May 1999. The six major events since 1972 were all triggered by long-lasting rainfall. Using the Mann-Kendall test, no statistically significant trend can be observed. 
Table 2. Monthly distribution of damage from 1972-2007 with respect to different processes and in total.

\begin{tabular}{lrrrrrr}
\hline \multirow{2}{*}{ Month } & \multicolumn{3}{c}{ Proportion of damage according to process [\%] } & & Total [\%] & Total [million $€$ ] \\
\cline { 2 - 6 } & Flood/inundation & Debris flow & Landslide & Rockfall (since 2002) & & \\
\hline January & 0.2 & $<0.1$ & 0.1 & $<0.1$ & 0.4 & 30 \\
February & 0.8 & 0.4 & 0.5 & $<0.1$ & 1.8 & 140 \\
March & 0.2 & $<0.1$ & 0.2 & $<0.1$ & 0.4 & 30 \\
April & 0.2 & $<0.1$ & 0.5 & $<0.1$ & 0.6 & 50 \\
May & 6.4 & 0.2 & 0.9 & 0.1 & 7.6 & 610 \\
June & 8.0 & 0.2 & 0.3 & $<0.1$ & 8.5 & 675 \\
July & 12.9 & 1.0 & 0.7 & $<0.1$ & 14.5 & 1160 \\
August & 46.2 & 1.2 & 1.9 & $<0.1$ & 49.4 & 3945 \\
September & 8.5 & 0.1 & 0.3 & $<0.1$ & 8.8 & 705 \\
October & 4.7 & 0.7 & 0.4 & $<0.1$ & 5.8 & 465 \\
November & 0.6 & 0.5 & 0.7 & $<0.1$ & 1.8 & 140 \\
December & 0.4 & $<0.1$ & $<0.1$ & $<0.1$ & 0.4 & 35 \\
\hline Total & 89.0 & 4.3 & 6.5 & 0.2 & 100.0 & 7985 \\
\hline
\end{tabular}

Table 3. Monthly distribution of damage from 1972-2007 with respect to triggering weather conditions and in total.

\begin{tabular}{lrrrrrr}
\hline \multirow{2}{*}{ Month } & \multicolumn{2}{c}{ Proportion of damage according to triggering weather condition [\%] } & \multirow{2}{*}{ Total [\%] } & Total [million $€$ ] \\
\cline { 2 - 5 } & Long-lasting rainfall & Thunderstorm & Snowmelt & Unknown/other cause & & \\
\hline January & 0.2 & $<0.1$ & $<0.1$ & 0.1 & 0.4 & 30 \\
February & 1.6 & 0.1 & $<0.1$ & $<0.1$ & 1.8 & 140 \\
March & 0.3 & $<0.1$ & $<0.1$ & $<0.1$ & 0.4 & 30 \\
April & 0.3 & $<0.1$ & 0.1 & 0.1 & 0.6 & 7.6 \\
May & 6.4 & 0.9 & $<0.1$ & 0.1 & 8.5 & 610 \\
June & 1.9 & 6.3 & 0.2 & $<0.1$ & 14.5 & 675 \\
July & 6.1 & 8.4 & $<0.1$ & $<0.1$ & 49.4 & 1160 \\
August & 42.8 & 6.5 & $<0.1$ & $<0.1$ & 8.8 & 3945 \\
September & 7.9 & 0.9 & 0 & $<0.1$ & 1.8 & 705 \\
October & 5.7 & 0.1 & 0 & $<0.1$ & 0.4 & 465 \\
November & 1.7 & 0 & 0 & 1.2 & 100.0 & 140 \\
December & 0.1 & 0 & 0.2 & & 35 \\
\hline Total & 75.0 & 23.2 & 0.6 & & 7985 \\
\hline
\end{tabular}

The distributions of the total cost of damage for each month of the year (from 1972 to 2007) are given in Table 2 according to the processes that occurred and in Table 3 according to the triggering weather conditions. Since 1972, nearly $50 \%$ of damage has been registered in the month of August, but the three events in August 1978, August 1987 and August 2005 (Table 4) already represent $40 \%$ of the total sum. $72 \%$ of the costs have been recorded in summer (June to August), $16 \%$ in autumn (September to November), $9 \%$ in spring (March to May) and 3\% in winter (December to February). Hence, $95 \%$ of the total costs were registered in the six months from May to October. The most important damage caused by floods and debris flows occurred in the months of August and July. Landslide damage is more frequent in August and May. Since 2002 rockfalls have mainly caused damage in May.
Long-lasting rainfall clearly caused the most serious damage in August. Except for June, July and December (when thunderstorms or snowmelt were also important factors), long-lasting rainfall accounted for $50-98 \%$ of the monthly costs. As expected, thunderstorms caused major damage mainly in the months from June to August.

Regarding the types of objects affected, $77 \%$ of the total costs concerned material assets, 19\% infrastructure and 4\% forestry and agricultural land. Taking the different processes into account, $80 \%$ of the damage caused by floods and debris flows were to material assets, and $17 \%$ to infrastructure (Fig. 2). Landslides and rockfalls affected both types of objects in nearly the same extent $(43 \%)$. 
Table 4. Dates of the six major events since 1972, their financial costs and the regions affected.

\begin{tabular}{llll}
\hline Date & $\begin{array}{l}\text { Financial loss (rounded) } \\
{[\text { million } € \text { ] }}\end{array}$ & $\begin{array}{l}\% \text { of the total financial } \\
\text { loss 1972-2007 }\end{array}$ & $\begin{array}{l}\text { Most affected regions } \\
\text { (numbers according to Fig. 3) }\end{array}$ \\
\hline 7-8 August 1978 & 610 & $8 \%$ & $4,5,7$ \\
24-25 August 1987 & 680 & $9 \%$ & $1,6,7$ \\
24 September 1993 & 460 & $6 \%$ & 1,7 \\
11-15/20-22 May 1999 & 380 & $5 \%$ & $2,3,4,5,6$ \\
14-15 October 2000 & 440 & $5 \%$ & 1,7 \\
21-22 August 2005 & 1870 & $23 \%$ & $2,3,4,5,6$ \\
\hline Total major events & 4440 & $56 \%$ & - \\
\hline
\end{tabular}

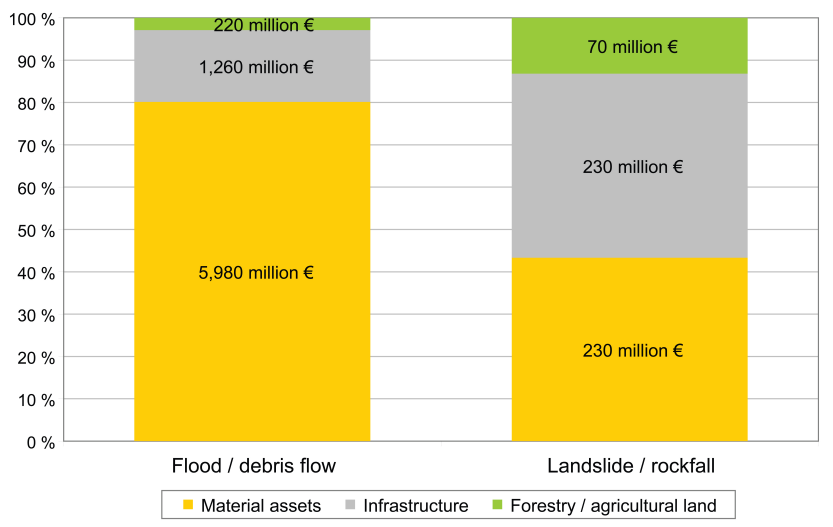

Fig. 2. Percentage and absolute values of the cost of damage caused by floods/debris flows and by landslides/rockfalls to different types of objects for the period 1972-2007.

Figures 3 and 4 show the spatial distribution of the cost of damage in Switzerland from 1972 to 2007 according to local authority and/or region. The regions Espace Midland and Central Switzerland each accounted for more than one quarter of the absolute total loss recorded. The alpine communities in these regions suffered particularly high levels of damage. Nearly $30 \%$ of the total damage occurred in the regions Lake Geneva and Ticino, whereas in some parts of western Switzerland, the Jura and Canton Grisons little damage was registered. Previous studies of the spatial distribution of different damaging processes are given in Schmid et al. (2004).

In the period 1972-2007, 102 persons lost their lives due to floods, debris flows or landslides (Fig. 5). With 46 fatalities, floods and inundations were the main cause of deaths, but not all kind of fatalities are recorded. People practising higher risk sports are presumably aware of the danger and take voluntary risks. Therefore, the 21 deaths during the canyoning catastrophe in 1999 in the Saxetbach (Canton Bern) were not counted in the analysis (Schmid et al., 2004). Landslides led to 32 fatalities and debris flows to 24 . In addition, since their systematic collection, rockfall events have claimed eight victims or 30\% of the fatalities in the period 2002-2007.

The natural hazards monitored in the presented database caused an average of three lives a year, but without any clearly identifiable trend $(p=0.14)$. The distribution of fatalities over the last 36 years has been very irregular, and even six financially very costly events (see Sect. 3.2) did not necessarily involve higher-than-average casualties. Eleven people died in August 1978, 16 in October 2000 and six in August 2005, but in August 1987 there was only one fatality and in September 1993 and May 1999 there were only two fatalities. On the other hand, six people lost their lives in July 1981 due to a debris flow which caused little financial loss.

\subsection{The six major events since 1972}

In this section we discuss the six major flood events registered in the damage database since 1972 (Table 4).

On 7-8 August 1978 intensive rainfall caused damage amounting to roughly 610 million Euros. The event affected mainly the Canton Ticino in the south of Switzerland and the Thur river catchment in the north of the country (Fig. 6). Damage to material assets due to streams overflowing, debris flows and landslides caused $85 \%$ of the total costs.

The second largest event since 1972 occurred on 2425 August 1987, when large parts of the Alpine region were severely affected. Fluvial erosion occurred along the River Reuss, causing dyke failures and the undermining of roads (BWW, 1991; Jordan and Petrascheck, 2004). The associated debris flows led to substantial losses, e.g. in Münster in Canton Valais. Approximately $80 \%$ of the total costs, which amounted to 680 million Euros, were paid for by the public hand to repair or replace damaged or destroyed infrastructure like protective structures, roads and railway lines (BWG, 2002).

Long-lasting rainfall on 24 September 1993 over southern Switzerland (Cantons Valais and Ticino) led to damage of 460 million Euros. Damage to material goods (buildings and chattels) amounted to more than 50\%. In Upper Valais (e.g. in the municipality of Brig-Glis) the occurrence 


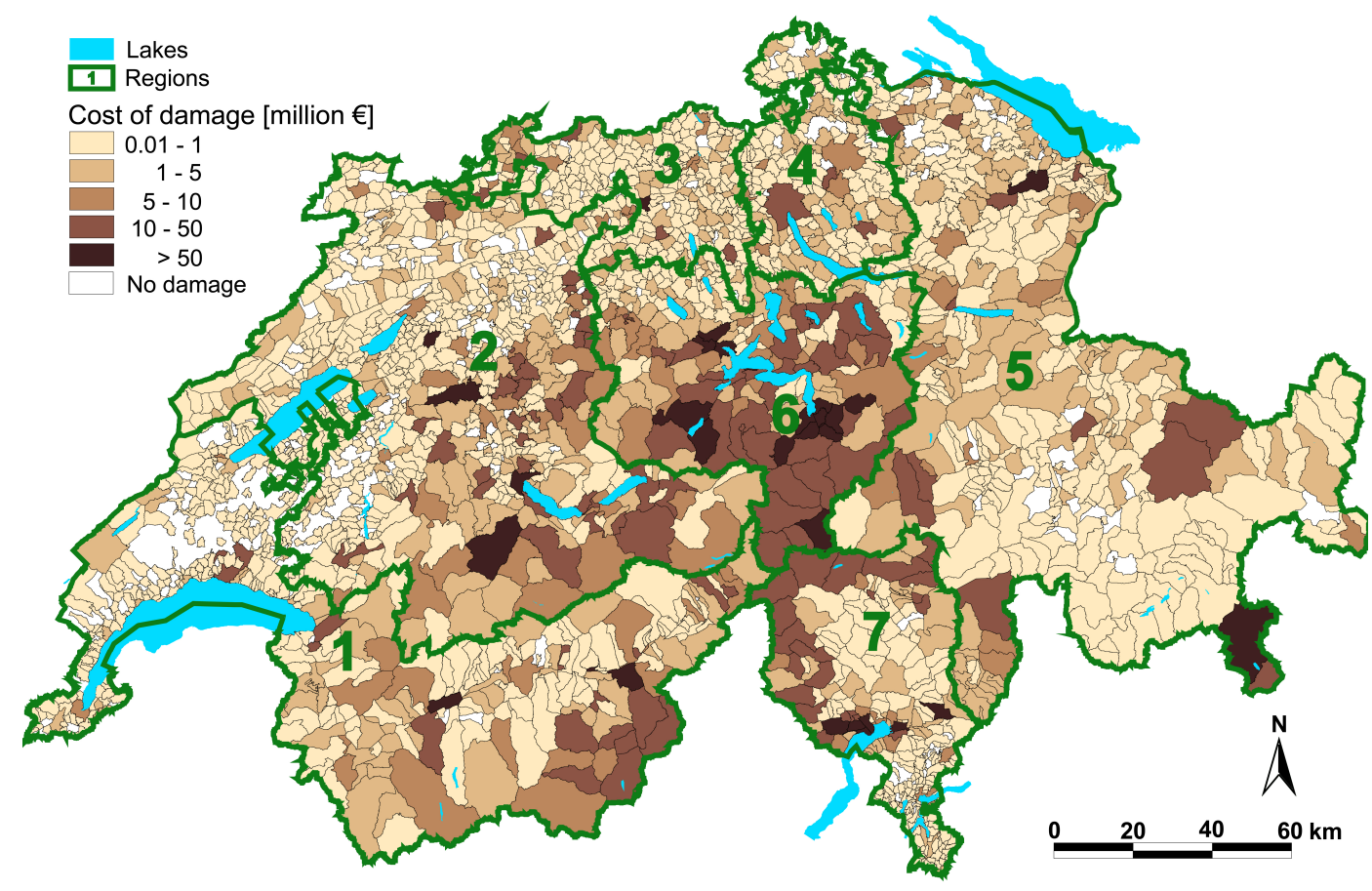

Fig. 3. Map of Switzerland with the distribution of the total of damage 1972-2007 on the community level. Damage that cannot be assigned to a certain local authority has been recorded in the dataset of the affected canton's capital or the Swiss capital Bern. Therefore, e.g. Sion in Valais, Bellinzona in Ticino and St. Gallen in the same named canton may be shown with a higher cost of damage than they really have. Regions according to the Swiss Federal Statistical Office: 1. Region Lake Geneva (Cantons Geneva, Vaud and Valais), 2. Espace Midland (Cantons Neuchâtel, Jura, Bern, Fribourg and Solothurn), 3. Northwestern Switzerland (Cantons Baselstadt, Basellandschaft and Aargau), 4. Zurich, 5. Eastern Switzerland (Cantons Schaffhausen, Thurgau, St. Gallen, Appenzell Innerrhoden and Ausserrhoden, Glarus and the Grisons), 6. Central Switzerland (Cantons Lucerne, Zug, Schwyz, Obwalden, Nidwalden and Uri), 7. Ticino.

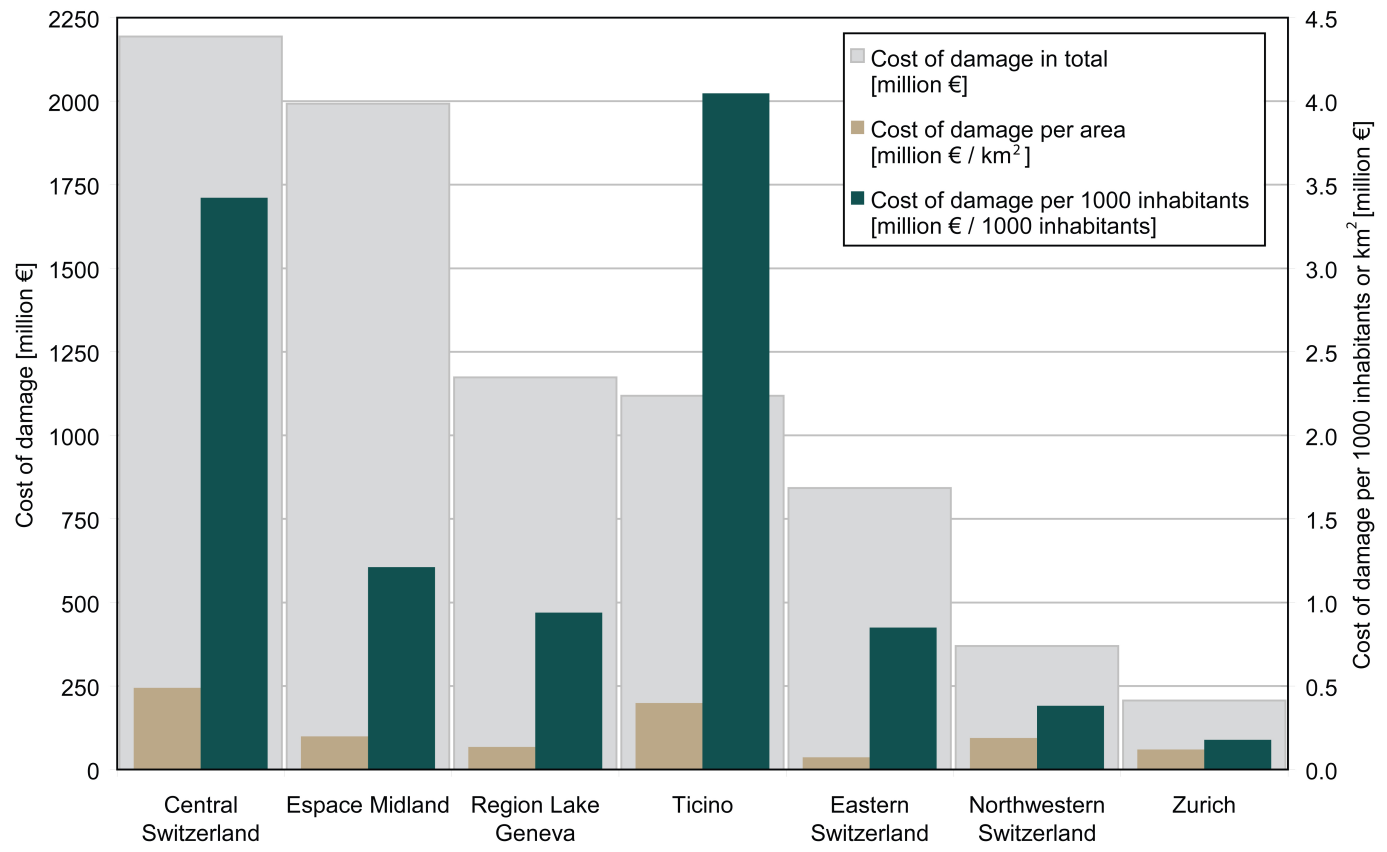

Fig. 4. Cost of damage by region for the period 1972-2007. For better comparability, the costs per area as well as per 1000 inhabitants are charted as well. 


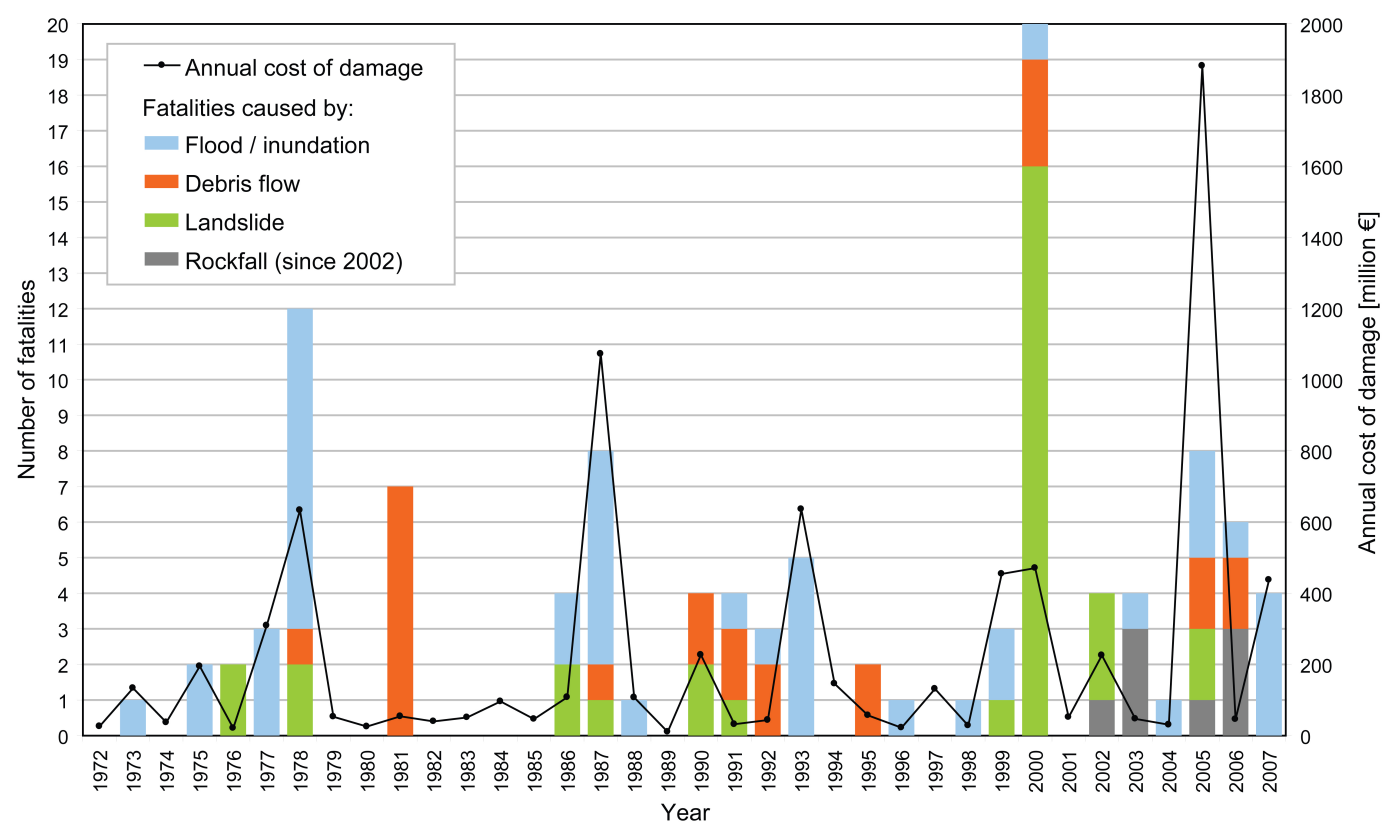

Fig. 5. Distribution of fatalities caused by the different processes and the annual cost of damage in the period $1972-2007$.

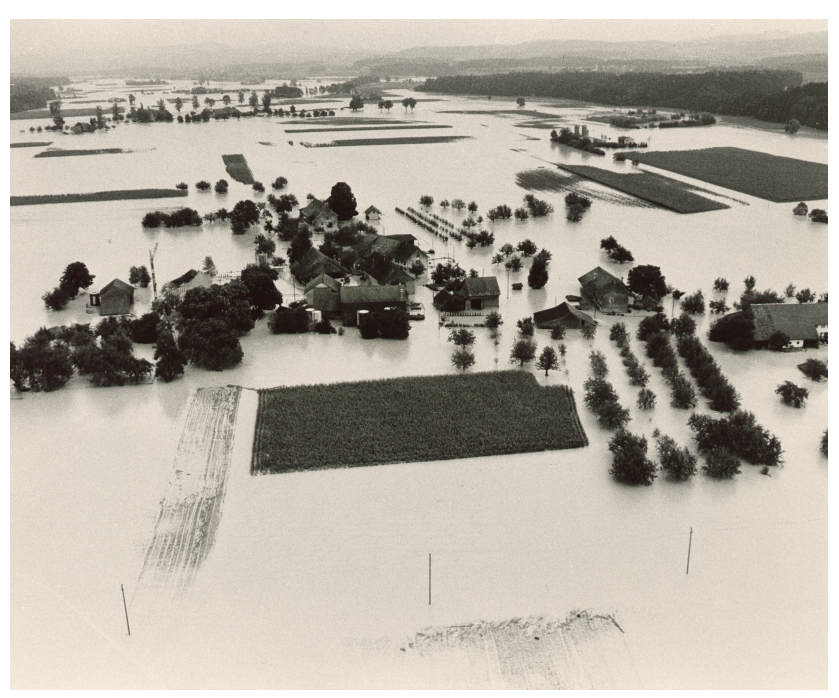

Fig. 6. River Thur flooding in the community of Altikon (Canton Zurich) on 7-9 August 1978 (photo: Office for Building and Construction Canton Zurich, AWEL).

of excessive sediment transport and subsequent deposition led to a large part of the recorded damage.

Two major flood events occurred in May 1999 (11-15 and 20-22 May), which, in the analysis (BWG, 2000), are taken together as one event. The total cost of damage amounted to 380 million Euros. The most affected region was the Swiss Midlands (especially the part stretching from Bern to Eastern Switzerland), where flooding on lake shores and along some of the larger rivers led to considerable damage, most notably in settled areas.

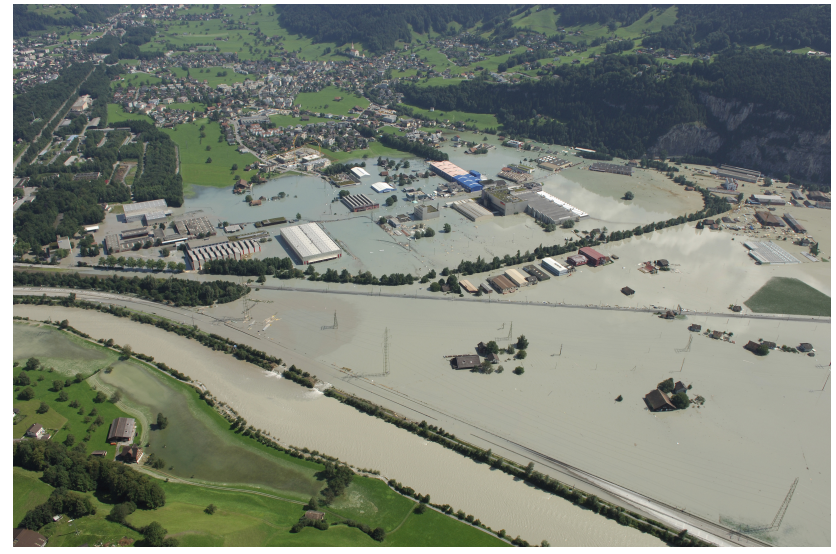

Fig. 7. Inundation by the Schaechen River (before flowing into the River Reuss) in an industrial area in Canton Uri (Central Switzerland) on 25 August 2005 (photo: Swiss Air Force).

On 14-15 October 2000 long-lasting rainfall caused damage of about 440 million Euros (BWG, 2002). In the most affected Canton Valais, 16 people lost their lives, 13 of them due to a large slope-type debris flow in the village of Gondo. In the Canton Ticino, the material damage was restricted to the shore area along Lake Maggiore, where mainly buildings were inundated.

The flooding on 21-22 August 2005 was the most costly event since the beginning of the systematic data collection in 1972 with a total financial loss amounting to approximately 1870 million Euros. Nearly every third Swiss community was affected in some way. Major flood damage extended 
from large rivers in the Midlands (e.g. along the Aare and Reuss rivers), over the northern foothills of the Alps to Central Switzerland. 95\% of the damage was caused by flooding, inundation, a ground-water surge, surface runoff or debris flows. Floods caused particularly high loss in settled areas especially in industrial areas (Fig. 7). The most costly debris flow happened in the Bernese Oberland (Glyssibach, Brienz). Landslides were particularly frequent in the region stretching from the northern foothills of the Alps to Canton Grisons and caused $5 \%$ of all costs. Only $25 \%$ of the total damage in August 2005 was related to infrastructure like protective structures (hydraulic engineering), roads and railway lines. Around $75 \%$ of the damage was to property like buildings and chattels.

\section{Discussion}

\subsection{Development of damage}

We did not find a statistically significant trend with regard to an increase in the annual cost of damage in the period from 1972 to 2007, but the observation period of 36 years is probably too short to identify a clear trend. On the other hand, it is difficult to quantify factors such as the changing loss potential, climate change and the effectiveness of protection structures or emergency measures and how they influence the total cost of damage. Furthermore, since only damage-causing events are recorded in our database, it is not possible to draw conclusions about how frequently these natural hazard processes occur or about their intensity per se (Swiss Re, 2003). Nevertheless, analyses of reinsurance companies indicate that insured flood losses have been rising worldwide by $7 \%$ annually in real terms since 1970 (Swiss $\mathrm{Re}, 2008)$. A possible explanation could be that higher values are being insured or that risk objects are more vulnerable, or indeed that global warming might accelerates the hydrologic cycle (Ohmura and Wild, 2002). An increase in heavy precipitation mainly in the winter months due to climate change is widely predicted by the scientific community (Frei et al., 1998; OcCC and ProClim, 2007; Rebetez and Reinhard, 2008). A statistically-significant increase of intense rainfall events in the past has been observed. However, it is not possible to detect or exclude an increase of the frequency of extreme events (OcCC, 2003). However, our database can neither confirm nor reject any prediction on the basis of the damage that has occurred up to now.

The reason why the recorded damage due to debris flows has increased since 1972 must not necessarily be the rising number of events of this type. We rather hypothesize that the authors of our information sources have become more familiar with such technical terms because of the recent reporting of major natural hazard events. This automatically leads to a more accurate and correct distinction between debris flows and landslides/floods in the Swiss media. Thus, the apparent increase in debris flow damage could be due to an increase in the number of entries in press articles instead of an actual intensification of the process.

\subsection{Affected objects}

Floods and debris flows mainly caused damage to material assets, whereas landslides led to nearly the same amount of damage to infrastructure as to material goods (Fig. 2). This was expected, as processes linked to the redistribution of water masses cause less damage to roads or other linear objects than sliding processes do. Moreover, lakes and rivers can damage adjacent residential areas and protection works when they overflow, through, e.g. erosion or scouring. It should, however, be noted that it was not always possible to distinguish between the categories material assets, traffic lines/infrastructure and forestry/agricultural land for every event that has occurred since 1972.

\subsection{Spatial distribution of damage}

The regional distribution of the total sum of damage from 1972 to 2007 (Fig. 3) indicates a concentration of high costs in Central Switzerland and in the Alps. This points out that high costs of damage are often found where relief energy and national infrastructure come together (as it is the case in the canton Uri). Relatively slight or no damage was registered in some communities in the western part of Switzerland and some other places. A lower event frequency or less costly events in this part of the country is probable, but we also assume that events are less reported in the press in the French-speaking part of Switzerland (parts of the regions Lake Geneva and Northwestern Switzerland) and in some alpine regions (e.g. parts of Canton Grisons). However, such speculations are based on a visual interpretation of Fig. 4, with little statistical evidence to support it. Within the region Lake Geneva (Figs. 3 and 4), Canton Valais is where the greatest part of the comparatively high amount of damage occurred, e.g. during the major events in 1993 and 2000. In the Espace Midland Canton Bern was where most damage occurred. This indicates the importance of classifying the data on a community level in order to be able to make valuable statements about the spatial distribution of damage caused by natural hazards.

Figure 4 illustrates the necessity of converting the total financial loss into loss per inhabitant and/or per area to indicate the real impact on a region. From the economic point of view (e.g. for insurance companies), the total cost of damage per capita is an important parameter. According to this criterion, Ticino has been the most affected region since 1972 (this region ranks fourth in terms of the total amount of damage), closely followed by Central Switzerland. From the scientific point of view, the total cost of damage per area better specifies the frequency of events in space. Using this parameter to rank the regions, Central Switzerland has been slightly more 
affected than Ticino. If we only consider the six major events since 1972 (not displayed in Fig. 4), the regions Espace Midland and Lake Geneva exchange their ranks concerning cost of damage in total and per capita. This indicates that there are numerous low-damage events in the region Espace Midland which lead together with the major events to the high total cost of damage. But apart from that, differences to Fig. 4 are marginal.

Regarding the regions affected by the six major events since 1972 (Table 4), the floods in the years 1993 and 2000 as well as those in the years 1999 and 2005 had a similar spatial distribution. In the time perspective of 36 years, the event in August 2005 seems to have been extraordinary. On the other hand, there were several events in the 19th century of the same order of magnitude, according to Röthlisberger (1991). Consequently, if longer periods are considered, the size and extent of the flooding in 2005 can no longer be seen as so extraordinary. We must therefore assume that major events like this will occur again in the future.

\subsection{Fatalities}

We have recorded an average of three fatalities per year since the beginning of data collection. Compared to the 25 deaths per year due to snow avalanches in Switzerland (Tschirky et al., 2000), this number may seem rather small. But the fatalities in avalanches include people doing higher risk sports, e.g. ski tours. As declared above fatalities due to risk sports accidents are not recorded in our database. Rockfall accidents claimed eight victims in Switzerland in six years, and we expect that this process will influence the number of casualties recorded in our database in the future.

\subsection{Advantages and disadvantages of the methodology}

The methodology we used has both advantages and disadvantages that affect the applicability of the damage database. The most important benefits are:

- the database includes data for the whole country at a good spatial resolution down to the level of the community;

- the data set is relatively long (36 years) and is based on continuous and consistent data collection carried out by just one institution since 1972 with only a few different people involved;

- data acquisition was efficient (A media monitoring company scans press articles, so there is no need for inspection in the field and one single person is in charge of data collection for particular periods);

- recording the data in the FileMaker form linked to a GIS is easy to do;
- it is possible to analyse the data focussing on different aspects (space, time, process, weather conditions, and affected objects); and

- the database can be used in natural hazard mapping.

The limitations of the database have mainly to do with:

- the fact that the amount of damage can only be estimated;

- the information found in the sources is often incomplete or incorrect as not every damage-causing event is recorded; there are regional and temporal variations in the quality of reporting events and no technical reports;

- it is sometimes difficult to decide whether fatalities were related to voluntary high-risk activity or not, i.e. whether we include them in the database or not;

- the fact that rockfall events were not collected until 2002 limits the analysis;

- the fact that 36 years of data for the other processes is still too short to detect significant statistical trends. In this study we used a significance level of 0.1 , but 0.05 or even 0.01 would be preferable to indicate a real trend.

To improve our estimates, access to more insurance and official data would have been helpful. On the other hand, this would complicate the data collection. When considering, e.g. a whole year or just major events, loss data seem to be fairly reliable, whereas problems arise only if individual smaller events are analysed or just one affected community is considered.

\section{Conclusions and outlook}

In the period 1972-2007, we recorded for Switzerland an estimated monetary loss amounting to approximately 8000 million Euros in total due to floods, debris flows, landslides and rockfall with rockfalls only recorded since 2002. About $56 \%$ of this damage was caused by six single flood events in the years 1978, 1987, 1993, 1999, 2000 and 2005. This fact shows the importance of extraordinary events in long term damage statistics. However, there is a general problem when comparing events with different scales in terms of intensity and spatial extent.

Because most scientists predict an increase of damagecausing events due to climate change, the absence of a trend in our data seems astonishing. Possible reasons for this absence are discussed in this article. Regarding the different natural hazard events investigated, $89 \%$ of the total amount of damage since 1972 was the result of floods and inundations. We observed that $95 \%$ of the total damage occurred in the half year from May to October. 
How aware the public is of the database varies with region. Further efforts should be undertaken to promote awareness among the local authorities and engineering companies carrying out natural hazard mapping.

For some recent large events, this damage database has become part of more extensive event analyses that take into account scientific, political and economic issues (e.g. Bezzola and Hegg, 2007). In the future, the damage database could also play a role in the development of guidelines for cost-loss analysis in hydrological forecasting (Roulin, 2007; Zappa et al., 2008), which could draw on our experience with natural hazard events and their impact. Furthermore, once we have a longer time series, we should be able to analyse levels of damage before and after the construction of protective structures and thus assess their impact. Some modern protection measures against natural hazards have proved successful in the past, e.g. the comprehensive flood protection concept on the Engelberger Aa river in Canton Nidwalden (Tognacca et al., 2008). Our database should provide further evidence of the effectiveness of such measures in the long term.

Our experience with collecting the data could be useful in an exchange of know-how with other institutions and for further discussion about how to deal with natural hazard damage data. The occurrence of very recent natural events like the extensive flooding in August 2005 are clear indicators of the need for a damage database to support decision making in natural hazard management.

Acknowledgements. We thank the Federal Office for the Environment FOEN for the contribution to the maintenance of the damage database. Furthermore, the authors would like to thank people previously involved in the database project: Alessia Bassi, Marielle Fraefel, Eva Frick, Dominik Gerber, Christoph Graf, Michel Jeisy, Gerhard Röthlisberger, Franziska Schmid and Jürg Zeller. Many thanks go to Peter Waldner for technical development and support as well as to Silvia Dingwall, Brian McArdell and Massimiliano Zappa for improving the quality of this paper. The authors kindly acknowledge the insightful and constructive comments of Gian Reto Bezzola, Matjaz Mikos and Armin Petrascheck on an earlier version of the manuscript.

Edited by: M. Mikos

Reviewed by: G. R. Bezzola and A. Petrascheck

\section{References}

Barnolas, M. and Llasat, M. C.: A flood geodatabase and its climatological applications: the case of Catalonia for the last century, Nat. Hazards Earth Syst. Sci., 7, 271-281, 2007, http://www.nat-hazards-earth-syst-sci.net/7/271/2007/.

Bezzola, G. R. and Hegg, C. (Eds.): Ereignisanalyse Hochwasser 2005, Teil 1 - Prozesse, Schäden und erste Einordnung, Bundesamt für Umwelt BAFU, Eidg. Forschungsanstalt WSL, UmweltWissen Nr. 0707, 215 pp., 2007.

Blong, R.: Issues in Risk Science, Natural Hazards Risk Assessment: An Australian Perspective, Benfield Hazard Research Centre, 27 pp., 2004.
Bundesamt für Wasser und Geologie BWG: Hochwasser 1999 Analyse der Ereignisse, Studienbericht Nr. 10, BBL/EDMZ, Bern, 148 pp., 2000.

Bundesamt für Wasser und Geologie BWG: Hochwasser 2000 Ereignisanalyse/Fallbeispiele, Berichte des BWG, Serie Wasser, Nr. 2, BBL, Bern, 248 pp., 2002.

Bundesamt für Wasserwirtschaft BWW (Ed.): Ursachenanalyse der Hochwasser 1987 - Schlussbericht, Bundesamt für Umwelt, Wald und Landschaft; Landeshydrologie und -geologie, Mitteilung des Bundesamtes für Wasserwirtschaft, Nr. 5, 47 pp., 1991.

Burren, S. and Eyer, W.: StorMe - Ein informatikgestützter Ereigniskataster der Schweiz, Internationales Symposion, Interpraevent 2000, Tagungspublikation, 1, 25-35, 2000.

Changnon, S. D.: Measures of Economic Impacts of Weather Extremes: Getting Better but Far from What Is Needed - A Call for Action, B. Am. Meteorol. Soc., 84, 1231-1235, 2003.

Chau, K. T., Sze, Y. L., Fung, M. K., Wong, W. Y., Fong, E. L., and Chan, L. C. P.: Landslide hazard analysis for Hong Kong using landslide inventory and GIS, Comput. Geosci., 30, 429443, 2004.

Chau, K. T., Wong, R. H. C., Liu, J., and Lee, C. F.: Rockfall Hazard Analysis for Hong Kong Based on Rockfall Inventory, Rock Mech. Rock Eng., 36(5), 383-408, 2003.

Creighton, R. (Ed.): Landslides in Ireland - A Report of the Irish Landslides Working Group, Dublin, Geological Survey of Ireland, Irish Landslides Working Group, 109 pp., 2006.

DesInventar: http://www.desinventar.org/en, last access: 21 August 2008.

Destatis - Federal Statistical Office of Germany: http://www. destatis.de, last access: 11 September 2008.

Devoli, G., Morales, A., and Høeg, K.: Historical landslides in Nicaragua - collection and analysis of data, Landslides, 4, 5-18, 2007.

Downton, M. W. and Pielke Jr., R. A.: How Accurate are Disaster Loss Data? The Case of U.S. Flood Damage, Nat. Hazards, 35, 211-228, 2005.

Federal Office for Water and Geology FOWG: Flood Control at Rivers and Streams - Guidelines of the FOWG, Berne, 72 pp., 2001.

Federal Statistical Office FSO and Federal Office for the Environment FOEN: Swiss Environmental Statistics: A Brief Guide 2008, available at: http://www.bfs.admin.ch,40pp., 2008.

Frei, C., Schär, C., Lüthi, D., and Davies, H. C.: Heavy precipitation processes in a warmer climate, Geophys. Res. Lett., 25, 14311434, 1998.

Gaspar, J. L., Goulart, C., Queiroz, G., Silveira, D., and Gomes, A.: Dynamic structure and data sets of a GIS database for geological riskanalysis in the Azores volcanic islands, Nat. Hazards Earth Syst. Sci., 4, 233-242, 2004, http://www.nat-hazards-earth-syst-sci.net/4/233/2004/.

Guha-Sapir, D. and Below, R.: The quality and accuracy of disaster data: A comparative analyse of three global data sets, Working paper prepared for the Disaster Management facility, World Bank, CRED, WHO Centre for Research on the Epidemiology of Disasters, University of Louvain School of Medicine, Brussels, 18 pp., 2002. 
Guzzetti, F., Stark, C. P., and Salvati, P.: Evaluation of Flood and Landslide Risk to the Population of Italy, Environ. Manage., 36(1), 15-36, 2005.

Guzzetti, F. and Tonelli, G.: Information system on hydrological and geomorphological catastrophes in Italy (SICI): a tool for managing landslide and flood hazards, Nat. Hazards Earth Syst. Sci., 4, 213-232, 2004,

http://www.nat-hazards-earth-syst-sci.net/4/213/2004/.

Hegg, C., Gerber, D., and Röthlisberger, G.: UnwetterschadenDatenbank der Schweiz, in: Internationales Symposion Interpraevent 2000 - Villach/Österreich, Tagungspublikation, Band 1, 37-48, 2000.

Hilker, N., Aller, D., and Hegg, C.: Schäden, in: Bezzola, G. R. and Hegg C. (Eds.): Ereignisanalyse Hochwasser 2005, Teil 1 Prozesse, Schäden und erste Einordnung, Bundesamt für Umwelt BAFU, Eidg. Forschungsanstalt WSL, Umwelt-Wissen Nr. 0707, 127-148, 2007.

Hilker, N., Badoux, A., and Hegg, C.: Unwetterschäden in der Schweiz im Jahre 2007, Wasser Energie Luft, 2, 115-123, 2008.

Hübl, J., Kienholz, H., and Loipersberger A. (Eds.): DOMODIS - Documentation of Mountain Disasters (State of Discussion in the European Mountain Areas), Internationale Forschungsgesellschaft INTERPRAEVENT, Schriftenreihe 1, Handbuch 1, Klagenfurt, 36 pp., 2002.

Jonkman, S. N.: Global Perspectives on Loss of Human Life Caused by Floods, Nat. Hazards, 34, 151-175, 2005.

Jordan, J. P. and Petrascheck, A.: Les crues de 1987 en Suisse, leurs consequences et enseignements - The 1987 Floods in Switzerland, consequences and lessons learnt, Houille Blanche, 6, 2832, 2004.

Komac, M., Fajfar, D., Ravnik, D., and Ribièiè, M.: Slovenian National Landslide DataBase - A promising approach to slope mass movement prevention plan, Geologija, 50(2), 393-402, 2007.

Marsh, T. and Hannaford, J.: The summer 2007 floods in England and Wales - a hydrological appraisal, Centre for Ecology \& Hydrology, 32 pp., 2007.

Merz, B.: Hochwasserrisiken - Grenzen und Möglichkeiten der Risikoabschätzung, Schweizerbart'sche Verlagsbuchhandlung (Nägele u. Obermiller), Stuttgart, 334 pp., 2006.

Merz, B., Kreibich, H., Thieken, A., and Schmidtke, R.: Estimation uncertainty of direct monetary flood damage to buildings, Nat. Hazards Earth Syst. Sci., 4, 153-163, 2004,

http://www.nat-hazards-earth-syst-sci.net/4/153/2004/.

Mitchell, J. K.: European river floods in a changing world, Risk Anal., 23(3), 567-574, 2003.

Munich Re Group: NatCatSERVICE - A guide to the Munich Re database for natural catastrophes, Münchener Rückversicherungs-Gesellschaft, Munich, 23 pp., 2003.

Munich Re Group: Topics Geo - Natural catastrophes 2007: Analyses, assessments, positions, Knowledge series, Münchener Rückversicherungs-Gesellschaft, Munich, 52 pp., 2008.

National Research Council: The Impacts of Natural Disasters: A Framework for Loss Estimation, Committee on Assessing the Costs of Natural Disasters, National Academy Press, Washington DC, 63 pp., 1999.

OcCC (Eds.): Extremereignisse und Klimaänderung, Bern, 88 pp., 2003

OcCC and ProClim (Eds.): Klimaänderung und die Schweiz 2050 - Erwartete Auswirkungen auf Umwelt, Gesellschaft und
Wirtschaft, Bern, 168 pp., 2007.

Ohmura, A. and Wild, M.: Is the Hydrological Cycle Accelerating?, Science, 298, 1345-1346, 2002.

Petley, D. N., Dunning, S. A., and Rosser, N. J.: The analysis of global landslide risk through the creation of a database of worldwide landslide fatalities, in: Landslide Risk Management, edited by: Hungr, O., Fell, R., Couture, R., and Eberhardt E., A. A. Balkema Publisher, Taylor \& Francis Group, London, 367-374, 2005.

Petrow, T., Thieken, A. H., Kreibich, H., Bahlburg, C. H., and Merz, B.: Improvements on Flood Alleviation in Germany: Lessons Learned from the Elbe Flood in August 2002, Environ. Manage., 38, 717-732, 2006.

Rebetez, M. and Reinhard, M.: Monthly air temperature trends in Switzerland 1901-2000 and 1975-2004, Theor. Appl. Climatol., 91, 27-34, 2008.

Röthlisberger, G.: Chronik der Unwetterschäden in der Schweiz, Berichte der Eidg. Forschungsanstalt WSL, Birmensdorf, 330, 122 pp., 1991.

Roulin, E.: Skill and relative economic value of medium-range hydrological ensemble predictions, Hydrol. Earth Syst. Sci., 11, 725-737, 2007, http://www.hydrol-earth-syst-sci.net/11/725/2007/.

Schmid, F., Fraefel, M., and Hegg, C.: Unwetterschäden in der Schweiz 1972-2002: Verteilung, Ursachen, Entwicklung, Wasser Energie Luft, 1/2, 21-28, 2004.

Smith, K. and Ward, R.: Floods - Physical Processes and Human Impacts, John Wiley \& Sons, Chichester, 394 pp., 1998.

Swiss Re: Natural catastrophes and reinsurance, Swiss Reinsurance Company, Zurich, 48 pp., 2003.

Swiss Re: Natural catastrophes and man-made disasters in 2007: high losses in Europe, sigma, No. 1/2008, Swiss Reinsurance Company, Zurich, 48 pp., 2008

Thieken, A. H., Petrow, T., Kreibich, H., and Merz, B.: Insurability and Mitigation of Flood Losses in Private Households in Germany, Risk Anal., 26(2), 383-395, 2006.

Tognacca, C., Kolb, R., and Eberli, J.: Entlastungsmassnahmen - Fallbeispiel Engelberger Aa, in: Ereignisanalyse Hochwasser 2005, Teil 2 - Analyse von Prozessen, Massnahmen und Gefahrengrundlagen, edited by: Bezzola, G. R. and Hegg, C., Bundesamt für Umwelt BAFU, Eidg. Forschungsanstalt WSL, Umwelt-Wissen Nr. 0825, 259-273, 2008.

Tropeano, D. and Turconi, L.: Using Historical Documents for Landslide, Debris Flow and Stream Flood Prevention. Applications in Northern Italy, Nat. Hazards, 31, 663-679, 2004.

Tschirky, F., Brabec, B. and Kern, M.: Lawinenunfälle in den Schweizer Alpen - Eine statistische Zusammenstellung mit den Schwerpunkten Verschüttung, Rettungsmethoden und Rettungsgeräte, in: Durch Lawinen verursachte Unfälle im Gebiet der Schweizer Alpen, edited by: Tschirky, F., Vorabdruck 2. Kapitel: Winterbericht des Eidg. Institutes SLF, Davos, 63/2000, 125$136,2000$.

Tschoegl, L., Below, R., and Guha-Sapir, D.: An Analytical Review of Selected Data Sets on Natural Disasters and Impacts, Paper prepared for the UNDP/CRED Workshop on improving Compilation of Reliable Data on Disaster Occurrence and Impact, UNDP/CRED, Bangkok, 21 pp., 2006.

UK Statistics Authority: http://www.statistics.gov.uk, last access: 11 September 2008 
Zappa, M., Rotach, M. W., Arpagaus, M., Dorninger, M., Hegg, C., Montani, A., Ranzi, R., Ament, F., Germann, U., Grossi, G., Jaun, S., Rossa, A., Vogt, S., Walser, A., Wehrhan, J., and Wunram, C.: MAP D-PHASE: real-time demonstration of hydrological ensemble prediction systems, Atmos. Sci. Lett., 9(2), 80-87, doi:10.1002/asl.183, 2008. 